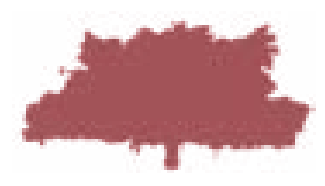

Recebido em: 22/08/2018

Aceito em: 09/09/2018

\title{
RESENHA
}

ONDJAKI. O convidador de pirilampos: estórias sem luz elétrica. Rio de Janeiro:

Pallas, 2018, 64 p.

\section{A POETICIDADE ANGOLANA DOS PIRILAMPOS}

Ana Claúdia dos Santos

O escritor angolano Ndalu de Almeida, pseudônimo Ondjaki, nasceu em Luanda em 1977. É membro da União dos Escritores Angolanos. Recebeu importantes prêmios em Angola. No Brasil, destacam-se os seguintes: em 2007, prêmio "Camilo Castelo Branco", com o livro de contos Os da minha rua; em 2010, Prêmio FNLIJ e Prêmio Jabuti na categoria Juvenil, com AvóDezanove e o segredo do soviético (romance); em 2012, Prêmio Bissaya Barreto de Literatura para a infância, com A bicicleta que tinha bigodes; em 2013, Prêmio FNLIJ com Uma escuridão bonita, e, no mesmo ano, com Os transparentes, o Prêmio José Saramago.

O convidador de pirilampos: estórias sem luz elétrica, obra literária de gênero ficção infanto-juvenil angolana, foi publicada pela primeira vez em Angola, no ano de 2017. Em 2018, foi editada no Brasil, sendo adaptada ao novo acordo ortográfico. O livro não apresenta sumário e as páginas não são numeradas. É todo ilustrado na cor preta, simbolizando a noite. No decorrer das páginas, percebe-se que a luz do luar clareia singelamente, resultando na cor cinza sobre a imagem da Grande Floresta, do Avô e do menino, protagonistas da história. Em seguida, as páginas vão sendo iluminadas de amarelo pela luz de pirilampos e assim segue por todo o texto. Esses são recursos interessantes utilizados pelo autor para expressar o encantamento de uma narrativa decorrida no escuro, à beira da floresta, e iluminada por pirilampos.

O texto narra a estória de um menino muito curioso e de seu Avô que moram perto da Grande Floresta. Segundo Ondjaki (2018), o menino gostava de "cientistar" e ler os pirilampos. O enredo se desenvolve em um ambiente aparentemente rural, rodeado de floresta e no período da noite, simbolizando a germinação tanto do espaço em volta dos personagens, quanto deles próprios. A partir dos momentos de diálogo entre o Avô e o menino, o menino e o pirilampo, o pirilampo e os "pirivelhos" e das contações de estórias, dá-se a ampliação do saber, inicia-se formação nova. 
Destaca-se, no início da narrativa, exemplar da beleza gerada pela tessitura textual: uma representação poética e ficcional do céu em noite de lua nova, singelamente vestido com pequenas e belas estrelas brilhantes, quase que desnudo. E na Terra, na Grande Floresta, brilham os pirilampos cintilantes.

A narrativa em primeira pessoa informa que o menino adorava passear à beira da Floresta. Mas, se fosse à noite, ou em noite de lua nova, o Avô sempre o acompanhava. Em um desses passeios noturnos, o menino levou a mochila com alguns de seus inventos. O primeiro deles era o "aumentador de caminhos", formado por um conjunto de três lentes, amarradas com arames e cordéis, que servia para mostrar o caminho aumentado a quem tivesse se perdido ou ajudava a chegar ao local a que se desejasse ir. Partindo desse, todos os equipamentos foram representados com detalhes e traços riquíssimos nas ilustrações no interior do livro.

A segunda invenção se tratava de um "unóculo", formado apenas por uma lente. Era a invenção preferida do menino, pois lhe permitia ler o brilho dos pirilampos. À medida que o menino ia mostrando as invenções, o Avô descascava uma cheirosa laranja com o canivete. Notamos que aquele cheiro da laranja penetrava o olfato e transferia o mais velho à memória do menino, fazia com que o Avô fosse lembrado, mesmo que estivesse em outro lugar, longe da criança. Esse detalhe inserido pelo autor, a lembrança através do cheiro, também estimula a memória adulta a buscar qual cheiro nos faz voltar a determinado tempo de nossa infância. Nossas lembranças podem estar associadas a alguns órgãos dos sentidos, seja pela visão, audição, tato, olfato ou paladar. Na narrativa, o autor insere o olfato: através do cheiro da laranja, o menino lembrava-se imediatamente do Avô.

Enfim, a terceira e última invenção é retirada cuidadosamente da mochila: uma pequena caixa que faz o Avô sorrir de orgulho, pois realmente o menino estava a "cientistar pirilampos".

O "convidador" funcionava da seguinte forma: o unóculo era pendurado na árvore na direção do aumentador de caminhos, que, por sua vez, era apoiado na pedra, ficando o "convidador de pirilampos" ao lado do "aumentador". Assim que o menino terminou de montar os equipamentos, foi para casa com o Avô; de lá retornaria posteriormente em busca de novidade. Algo fascinante aconteceu durante a noite, quando uma luz quase invisível entrou pelo "unóculo", passou pelo "aumentador de caminhos" e inventou um brilho que chegou ao "convidador de pirilampos". O brilho resultou em cores que dançavam vermelho, laranja, amarelo, azul, amarelo, verde, roxo, um verdadeiro arco-íris noturno.

Consistia em algo tão lindo e diferente, que os "pirivelhos" se negavam a ver, fechavam os olhos e voltavam para suas casas. Porém, os mais novos, deslumbrados com tamanha beleza, não apenas ficaram lá como entraram na caixinha e acabaram por ficar presos pelas patas em um mel cheiroso colocado pelo menino no chão do "convidador". 
No dia seguinte, acompanhado do Avô, o menino retornou à Floresta para pegar o convidador e os pirilampos. O Avô questionou o menino dizendo que aquilo não era "convidador" de pirilampos e sim uma armadilha, era um apanhador de pirilampos. Mas o menino insistiu dizendo que era um "convidador", e que teria uma casa (gaiola) especialmente reservada para eles junto a outros pirilampos já instalados no quintal. Logo, os pirilampos foram colocados na gaiola junto aos demais. A gaiola ficava em frente à janela do menino.

Certa noite, enquanto o menino observava os pirilampos, o Avô foi até o quarto do pequeno e ficou surpreso quando este último anunciou que sabia conversar com os pirilampos através do código Morse. Com a ajuda de uma lanterna, o menino piscava várias vezes e, surpreendentemente, os pirilampos respondiam. Em uma das conversas, o menino queria saber como eram chamados os outros que não acendiam. Um pirilampo cintilante disse que eram chamados de "pirivelhos" e eles não deviam ser aprisionados, porque consistiam em contadores de estórias muito antigas.

A conversa entre o pirilampo e o menino foi interrompida pelo desgaste da pilha da lanterna. Mas, rapidamente, o Avô buscou uma vela e ensinou o menino a dar continuidade ao assunto pelo código Morse.

Na manhã seguinte, após uma chuva, o chão cheirava à terra molhada. O pirilampo cintilante nomeado como Edilson começou a observar a reciprocidade do prazer sentido pelo Avô e pelo menino ao estabelecerem uma conversa, enquanto o primeiro descascava lentamente as laranjas cheirosas com o canivete.

À noite, o menino foi até a gaiola para conversar mais um pouco. No entanto, os pirilampos não brilhavam mais, pois não estavam em sua casa: a Grande Floresta. Segundo o pirilampo Edilson, o brilho não vinha da força dos corpos, mas sim da força das estórias contadas pelos "pirivelhos" e estes estavam na Floresta. O menino, triste, decidiu soltar os pirilampos e disse que ele também poderia contar estórias. A criança não sabia, mas, se não fizesse isso, as estórias dos pirilampos se perderiam para sempre, porque elas não têm dono, são da Floresta Grande, são do tempo.

Em seguida, o menino levou o "convidador" com os pirilampos e os deixou na Grande Floresta, libertando-os. Edilson pediu que o menino deixasse sua invenção aberta na Floresta, pois as cores por ela produzidas, além de serem fascinantes, poderiam convidar os "pirivelhos" a conhecer outros tons e, automaticamente, isso os estimularia à criação de novas estórias.

Ao se despedir de Edilson, o menino falou que estaria na janela da casa lendo as estórias que seriam contadas pelos “pirivelhos”. Desse modo, O convidador de pirilampos: estórias sem luz elétrica nos apresenta o encantamento de uma estória que relata casos preciosos e incomuns, cujo espaço se volta para locais sem luz elétrica à beira das florestas, cujas personagens são Avô 
em interação com criança que brinca e se encanta com as próprias invenções. Ainda nos alerta para o perigo da escassez da tradição de contar estórias, uma vez que estas estão sendo silenciadas pelo esquecimento das gerações. As pessoas não se reúnem mais em roda de contação de estórias no escuro convidativo.

Assim, Ondjaki chama atenção para a relevância de manter viva essa tradição, o que é confirmado no final da narrativa. Com o passar do tempo, Edilson envelhecera. O envelhecimento mostra-se irreversível, cumprindo-se o ciclo da vida. Agora "pirivelho", Edilson sempre conta a estória de um menino acompanhado de Avô com canivete a descascar laranjas cheirosas, perto da Grande Floresta. Esse menino "cientistava" pirilampos e aprendera a ser amigo do escuro. 